University of Nebraska - Lincoln

DigitalCommons@University of Nebraska - Lincoln

The George Eliot Review

English, Department of

1997

\title{
The Quest of Anonymity: The Novels of George Eliot
}

Henry Alley

Follow this and additional works at: https://digitalcommons.unl.edu/ger

Part of the Comparative Literature Commons, Literature in English, British Isles Commons, and the Women's Studies Commons

Alley, Henry, "The Quest of Anonymity: The Novels of George Eliot" (1997). The George Eliot Review. 324. https://digitalcommons.unl.edu/ger/324

This Article is brought to you for free and open access by the English, Department of at DigitalCommons@University of Nebraska - Lincoln. It has been accepted for inclusion in The George Eliot Review by an authorized administrator of DigitalCommons@University of Nebraska - Lincoln. 


\section{Henry Alley, The Quest for Anonymity: The Novels of George Eliot (Associated University Presses, 182 pp., 1997). ISBN 0874136210}

This book derives from half a lifetime's teaching and the author's obvious affinity for George Eliot. It is earnest, sometimes engaging, often off centre. It also exists in a kind of time-warp, somewhere in the 1960s in terms of tone and stance, though there is an impressive range of criticism and background reading cited and occasionally milked. In fact this back-up seems to be an attempt to establish critical credentials, and the constant references in which Alley says 'And I would add ...', or merely summarizes arguments reflect this. At his best he has no need of this, since when he goes to text he is sometimes better than most critics he mentions. My main quarrel with his method is that in citing so many he shows an incapacity to discriminate between the masqueraders, the band-waggoners, and the slavishly, politically correct. His own voice is at least an individual one, since he traces a path, or rather road, from Emmaus in an 1846 letter to Sara Hennell through the major fiction which is scrutinized with commendable dedication and occasional insight. Unfortunately the first reference (13) is inaccurate (it should be Letters I: 228) and there are other instances of passing error. This reference to Luke's Gospel, where Christ anonymous reveals himself as Christ defeated, was for the young Mary Ann Evans in 1846 an inspiring idea: 'And then there is the burning of the heart which assures that "This was the Lord!" that this is the inspiration from above - the true Comforter that leads into truth'. Alley links this persuasively to the fictional practice which follows and suggests that it is a major theme, that each novel has a "critical moment"'... when the heart "burns" in the presence of the yet undisclosed hero or heroine, one who is apparently vanquished but becomes truly victorious once the recognition finally arrives'. Now letters, we know, are a central adjunct to literary study, witness Rosemarie Bodenheimer's perceptive and sensitive linkages between the letter life, the life, and the printed fiction in what, in my view, is incomparably the best book on George Eliot to be published in the last decade. Having started with a letter written eleven years before George Eliot emerged to write fiction, there can be no going back for Alley. The run through the novels begins with Scenes of Clerical Life (which perhaps ought to have been omitted by definition, since it is not a novel but a series of three novellas), and it is highly selective. The introduction is cogent, virtually beginning with the burning moment experienced by Janet Dempster. But even this early there are strange emphases. Take this: 'Dorothea begins by hoping to be a prestigious hero: she ends by attaining the greater joy of being an anonymous one'. Surely both 'prestigious' and 'joy' are inaccurate, misguided words to apply to Dorothea naïve as well as Dorothea learning? Alley's language is so often imprecise or so personal that it fails to define. Can we really feel of Lydgate that he is 'the coordinate hero'? Gender equalization has already occurred with Dorothea as hero above, but the parallels between Dorothea and Lydgate have been sufficiently delved over the years. Some ellipses defy definition, though they sound good ('Character becomes recollection and resurrection'), while George Eliot 'wished to invoke a new deity for the age'. And there are some extraordinary statements: 'Just as one loses by becoming a reader, so does one gain. When the reader becomes Dorothea, he becomes both larger and smaller by becoming the woman he never could be; when she becomes Lydgate, she becomes both larger and smaller in the same way. Similarly, the moment we become the larger consciousness of Middlemarch, our egos both expand and contract'(28). 
This certainly merits more than a moment's thought. There is some good closework on Felix Holt and Daniel Deronda, and Alley conveys his enthusiasm for his subject. But there is too much straining and not enough directness.

\section{Graham Handley}

